\title{
Comparative Studies on Synthesis and Characterization of Titania and Iron Oxide Doped Magnesia from Indian Salem Magnesite
}

\author{
Sukriti Manna1,2, Tamoghna Chakrabarti ${ }^{3 *}$ \\ ${ }^{1}$ Department of Metallurgical and Material Engineering, Jadavpur University, Kolkata, India \\ ${ }^{2}$ Department of Mechanical Engineering, Colorado School of Mines, Golden, CO, USA \\ ${ }^{3}$ Department of Materials Engineering, Indian Institute of Science, Bangalore, India \\ Email: "tchakrabarti@mines.edu
}

Received 29 May 2016; accepted 22 July 2016; published 25 July 2016

Copyright (C) 2016 by authors and Scientific Research Publishing Inc.

This work is licensed under the Creative Commons Attribution International License (CC BY). http://creativecommons.org/licenses/by/4.0/

(c) (i) Open Access

\begin{abstract}
Sintering, densification, and characterization of Salem Magnesite with Titania $\left(\mathrm{TiO}_{2}\right)$ and Iron Oxide $\left(\mathrm{Fe}_{2} \mathrm{O}_{3}\right)$ addition have been carried out in this work. Salem Magnesite samples with $2 \mathrm{wt} . \% \mathrm{TiO}_{2}$ and $\mathrm{Fe}_{2} \mathrm{O}_{3}$ addition have been sintered in the temperature range of $1550^{\circ} \mathrm{C}-1650^{\circ} \mathrm{C}$. The sintered sample has been characterized in terms of physico-chemical properties like bulk density, apparent porosity, specific gravity and structural properties by X-ray diffraction and scanning electron microscope (SEM). Salem magnesite samples with 2 wt.\% $\mathrm{TiO}_{2}$ and $\mathrm{Fe}_{2} \mathrm{O}_{3}$ addition have been densified to the specific gravity of 3.75 and $3.41 \mathrm{~g} / \mathrm{cc}$ respectively after sintering at $1650^{\circ} \mathrm{C}$ and $2 \mathrm{~h}$. The presence of Calcium Titanate $\left(\mathrm{CaTiO}_{3}\right)$ phase at the grain boundary has been observed in the case of $\mathrm{TiO}_{2}$ addition. For Iron Oxide addition, precipitation of " $Y$ " shaped magnesium ferrite spinel has been observed inside the grains. Finally, $\mathrm{TiO}_{2}$ addition in Salem Magnesite shows better densification compared to both as received Salem Magnesite and Salem Magnesite with $\mathrm{Fe}_{2} \mathrm{O}_{3}$ addition.
\end{abstract}

\section{Keywords}

Sintering, Additive, Magnesite, Densification

\section{Introduction}

Magnesia (MgO) based refractories have been a subject of continuing interest because of its high melting point "Corresponding author.

How to cite this paper: Manna, S. and Chakrabarti, T. (2016) Comparative Studies on Synthesis and Characterization of Titania and Iron Oxide Doped Magnesia from Indian Salem Magnesite. Journal of Materials Science and Chemical Engineering, 4, 67-76. http://dx.doi.org/10.4236/msce.2016.47010 
$\left(2858^{\circ} \mathrm{C}\right)$, high chemical inertness against both acidic and basic slags, low thermal expansion (CTE) values at elevated temperatures and benign ecological characteristics [1]-[3]. It is widely used in various applications such as steel ladles, cement rotary kilns, vacuum induction furnaces, continuous casting tundishes, degasser snorkels and lances and glass industries [4]. During processing of refractory materials, densification occurs via sintering process [5]. Though a very high melting point of the refractory material is essential for high-temperature applications, lower temperature processing is always preferable to reduce processing expenses. Thus, the addition of small additive plays an important role in its processing (i.e. sintering) as they not only lower the sintering temperature but also can enhance its mechanical strength and corrosion resistance during operation. Several authors have reported that the small additions (often less than 2 wt.\%) of another material can have a very marked effect on the densification, grain growth and other characteristics of Magnesia refractory [6]-[9].

Magnesia refractories in India are manufactured mainly from naturally occurring magnesite mineral. Though India has vast reserves of natural magnesite, the Indian refractory industries are mostly reliant on imported magnesite. This is mainly due to the fact that Salem Magnesite contains impurities like Silica $\left(\mathrm{SiO}_{2}\right)$ and Calcia $(\mathrm{CaO})$ which degrade refractoriness of Magnesia refractory at elevated temperatures by forming low melting Calcium Silicate phase [10]. The addition of small amount of additives which can react with these unwanted impurities and form high melting phases instead can potentially improve the refractoriness of Magnesia refractory produced from Salem Magnesite. Additives also can help in sintering.

There have been numerous studies on Magnesite with different additives. James W. Nelson et al. have suggested that the Iron Oxide addition can promote sintering with cation vacancies [11]. Fresh has shown that the reaction between $\mathrm{MgO}$ and $\mathrm{Fe}_{2} \mathrm{O}_{3}$ occurs to form $\mathrm{MgFe}_{2} \mathrm{O}_{4}$ in the temperature region $900^{\circ} \mathrm{C}$ to $1200^{\circ} \mathrm{C}$ which is a high melting spinel phase [12]. Work done by Bron has shown that $\mathrm{Ti}^{4+}$ ions are capable of entering the $\mathrm{MgO}$ lattice with the formation of a defect structure which is very similar to the mixture of $\mathrm{Al}_{2} \mathrm{O}_{3}$ and $\mathrm{TiO}_{2}$ and help in densification [13]. According to Cosic et al., $\mathrm{MgO}$ and $\mathrm{TiO}_{2}$ react to form $\mathrm{MgTiO}_{3}$. This $\mathrm{MgTiO}_{3}$ transforms into $\mathrm{Mg}_{2} \mathrm{TiO}_{4}$ and $\mathrm{CaO}$ from $\mathrm{MgO}-\mathrm{CaO}$ solid solution reacts with $\mathrm{TiO}_{2}$ forming $\mathrm{CaTiO}_{3}$ [14]. Calcium Titanate is a high-temperature phase and formation of Calcium Titanate is preferable to low melting Calcium Silicate phase.

Even though Salem Magnesite is technologically important for refractory production, there has been a dearth of studies on Salem Magnesite with the additive addition to overcoming its inherent difficulty with impurities. The present work involves investigation of densification studies on the addition of dopants (additive) on Magnesia refractory aggregates produced from Salem Magnesite. The objectives of the present work are two folds. The first objective is to determine the influence of its physicochemical properties on dopant addition. The second objective is to correlate the mineralogical phases and as well as the microstructure of the developed phases in the presence of dopants. We have used Iron Oxide $\left(\mathrm{Fe}_{2} \mathrm{O}_{3}\right)$ and Titania $\left(\mathrm{TiO}_{2}\right)$ as additives. These additives are chosen because they have an ionic radius not too different from that of $\mathrm{Mg}^{2+}$ but a different valence; the idea behind is that they might form solid solutions with Magnesia (MgO) and effect the sintering through the formation of defects and the subsequent change in the rate of diffusion. The amount of additives added was 2 wt.\%.

\section{Experimental Procedure}

\subsection{Material and Processing}

For the present study natural Magnesite obtained from Salem district in Tamil Nadu (supplied by erstwhile Burn Standard Co. Ltd., presently SAIL Refractory Co. Ltd., India) was used as the base material. Commercially available powders of Iron Oxide $\left(\mathrm{Fe}_{2} \mathrm{O}_{3}\right.$, Glaxo Laboratories, India Ltd.) and Titania $\left(\mathrm{TiO}_{2}\right.$, S.D. Fine Chem. Ltd., Boisar, India) of reagent grade were used for this study. Starting Magnesite lumps were first characterized for chemical analysis and phase analysis. Chemical analysis was done by the acid dissolution method. Phase identification was done by X-ray diffractometer (Philips X' pert Pro, PAN Analytical operated at $40 \mathrm{KV}$ and 35 $\mathrm{mA}$, The Netherlands). Figure 1 shows the process flow chart of magnesia preparation from the Salem Magnesite. The magnesite, initially in the form of large aggregated lumps, was crushed in a jaw crusher and ground by hand rammer to the required fineness. The ground materials were sieved through BS 100 mesh sieves. Iron particles were separated from fine powders by using a U-shaped magnet. Then the fine powders were attrition milled using ethyl alcohol as a mixing media for $2 \mathrm{~h}$. at $200 \mathrm{rpm}$. The batches were then dried at $50^{\circ} \mathrm{C}$ (overnight). The dried materials were sieved through BS 60 mesh and then mixed with a binder ( 5 wt.\% poly-vinyl alcohol solution). Iron oxide and Titania were added separately. The bars of samples were prepared by filling approximately $7 \mathrm{gm}$. of powder mixtures in a toughened steel mold of length $7 \mathrm{~cm}$ and breadth $0.75 \mathrm{~cm}$ and then 
FLOW SHEET:

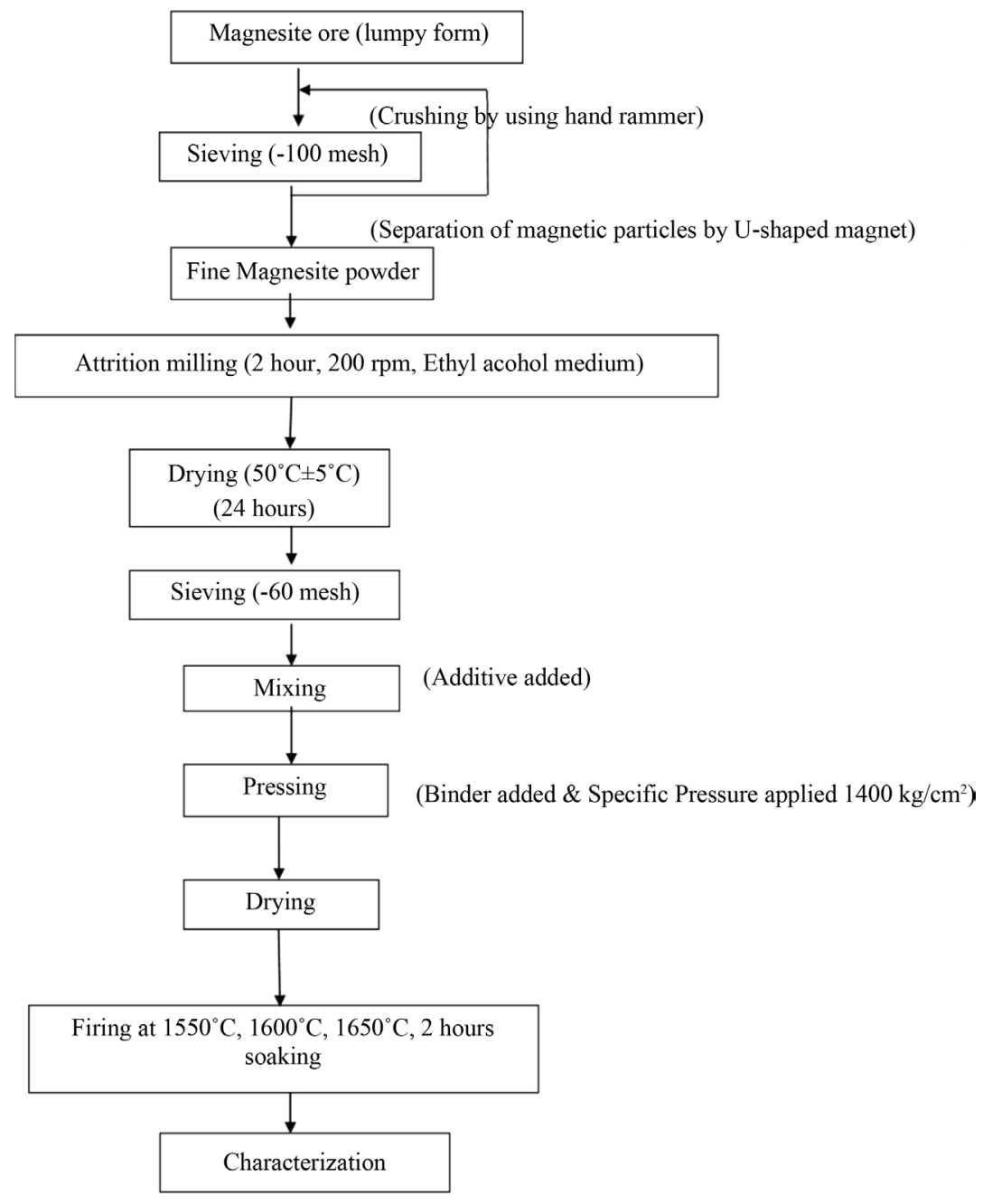

Figure 1. Process flow chart of sample preparation.

application of uniaxial pressure $1400 \mathrm{~kg} / \mathrm{cm}^{2}$. The pressure was applied in a hydraulic press (Fred S. Carver Inc., Wabash, IN, USA). The dried samples were then sintered in an electrically heated programmable furnace to $1550^{\circ} \mathrm{C}-1650^{\circ} \mathrm{C}$ with 2 hours of soaking at the peak temperature. The heating rate for the furnace was maintained $5^{\circ} \mathrm{C} / \mathrm{min}$ up to $1000^{\circ} \mathrm{C}$, then $3^{\circ} \mathrm{C} / \mathrm{min}$ up to the peak temperature. The samples were allowed to cool in the furnace before characterization in terms of their physical properties and structures.

\subsection{Characterization of the Sintered Samples}

Sintered samples were polished using SiC abrasive paper of different grit size and diamond paste. Post processing, characterization conducted were density measurements through Archimedes method in kerosene, X-ray diffraction (XRD) for phase identification (Philips X' pert Pro, PAN Analytical operated at $40 \mathrm{KV}$ and $35 \mathrm{~mA}$, The Netherlands) using CuKa radiation. Scanning electron microscopy (Zeiss, Germany) of the polished sample surface was carried out for the observation of microstructures and phase identification with energy-dispersive X-ray microanalysis (EDAX, Mahwah, NJ, USA).

\section{Results}

In this section, the phase analysis results are first reported, followed by the density and microstructural observations. 


\subsection{Chemical Analysis}

Table 1 shows the chemical analysis results. Salem Magnesite contains a significant amount of impurities. Important impurities on the basis of wt.\% are Silica $\left(\mathrm{SiO}_{2}\right)$ and Calcia $(\mathrm{CaO})$. Minor impurities are Alumina $\left(\mathrm{Al}_{2} \mathrm{O}_{3}\right)$, Iron Oxide, Titania, Potassium Oxide $\left(\mathrm{K}_{2} \mathrm{O}\right)$ and Sodium Oxide $\left(\mathrm{Na}_{2} \mathrm{O}\right)$.

\subsection{XRD Analysis}

\subsubsection{With $\mathrm{TiO}_{2}$ Addition}

Normalized XRD patterns of the Salem Magnesite with $\mathrm{TiO}_{2}$ addition after heat treatment at $1550^{\circ} \mathrm{C}, 1600^{\circ} \mathrm{C}$, and $1650^{\circ} \mathrm{C}$ are shown in Figures 2(a)-2(c). The presence of magnesium Titanate $\left(\mathrm{Mg}_{2} \mathrm{TiO}_{4}\right)$, Calcium Titanate $\left(\mathrm{CaTiO}_{3}\right)$ and Magnesium Silicate $\left(\mathrm{Mg}_{2} \mathrm{SiO}_{4}\right)$ phases in XRD pattern are identified. Binary phase diagram of MgO- $-\mathrm{TiO}_{2}$ shows stable phase for $3 \mathrm{wt} \% \mathrm{TiO}_{2}$ addition in $\mathrm{MgO}$ is $\mathrm{Mg}_{2} \mathrm{TiO}_{4}$ and $\mathrm{MgO}$. Our XRD results corroborate that. Our starting composition also has a significant amount of $\mathrm{SiO}_{2}$ and $\mathrm{CaO}$ as impurities. Our XRD results show the presence of $\mathrm{CaTiO}_{3}$ and $\mathrm{Mg}_{2} \mathrm{SiO}_{4}$ which form during the sintering when the impurity phase reacts with Periclase (MgO) and Titania $\left(\mathrm{TiO}_{2}\right)$ phase.

Table 1. Chemical analysis of the starting materials.

\begin{tabular}{ccc}
\hline Constituent & Weight (\%) & Weight (\%) on fired basis \\
$\mathrm{SiO}_{2}$ & 2.44 & 4.8 \\
$\mathrm{Al}_{2} \mathrm{O}_{3}$ & 0.17 & 0.34 \\
$\mathrm{Fe}_{2} \mathrm{O}_{3}$ & 0.24 & 0.48 \\
$\mathrm{TiO}_{2}$ & 0.02 & 0.4 \\
$\mathrm{CaO}$ & 1.41 & 2.79 \\
$\mathrm{MgO}$ & 45.68 & 90.49 \\
$\mathrm{Na}_{2} \mathrm{O}$ & 0.08 & 0.16 \\
$\mathrm{~K}_{2} \mathrm{O}$ & 0.05 & 0.99 \\
L.O.I. & 49.52 & - \\
\hline
\end{tabular}

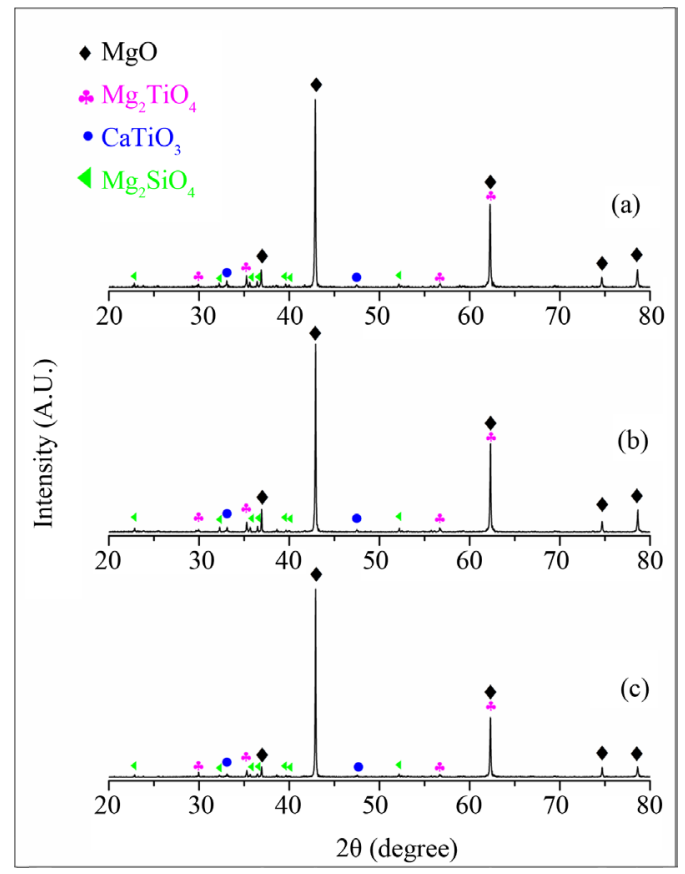

Figure 2. Phase analysis of Indian magnesite with Titania additive after sintering at (a) $1550^{\circ} \mathrm{C}$, (b) $1600^{\circ} \mathrm{C}$ and (c) $1650^{\circ} \mathrm{C}$. 


\subsubsection{With $\mathrm{Fe}_{2} \mathrm{O}_{3}$ Addition}

XRD patterns of the Salem Magnesite with $\mathrm{Fe}_{2} \mathrm{O}_{3}$ addition after sintering at $1550^{\circ} \mathrm{C}, 1600^{\circ} \mathrm{C}$ and $1650^{\circ} \mathrm{C}$ are shown in Figures 3(a)-3(c). XRD pattern after sintering has confirmed the formation of Magnesium Ferrite $\left(\mathrm{MgFe}_{2} \mathrm{O}_{4}\right)$ spinel mainly by counter diffusion of cations through oxygen lattice. Phase diagram of $\mathrm{MgO}-\mathrm{Fe}_{2} \mathrm{O}_{3}$ shows that over the temperature of $1400^{\circ} \mathrm{C}$, the reaction occurs between $\mathrm{MgO}-\mathrm{Fe}_{2} \mathrm{O}_{3}$ to form a $\mathrm{MgFe}_{2} \mathrm{O}_{4}$ spinel. Our XRD results support that. Our starting composition also has a significant amount of $\mathrm{CaO}$ and $\mathrm{SiO}_{2}$. Consequently, our XRD results also show the presence of Calcium Magnesio Silicate $\left(\mathrm{CaMgSiO}_{4}\right)$ and $\mathrm{Mg}_{2} \mathrm{SiO}_{4}$ which have formed during the sintering.

\subsection{Sintering and Densification}

Bulk density and apparent porosity with $\mathrm{TiO}_{2}$ addition in Magnesia are shown in Figure 4. Here, the significant

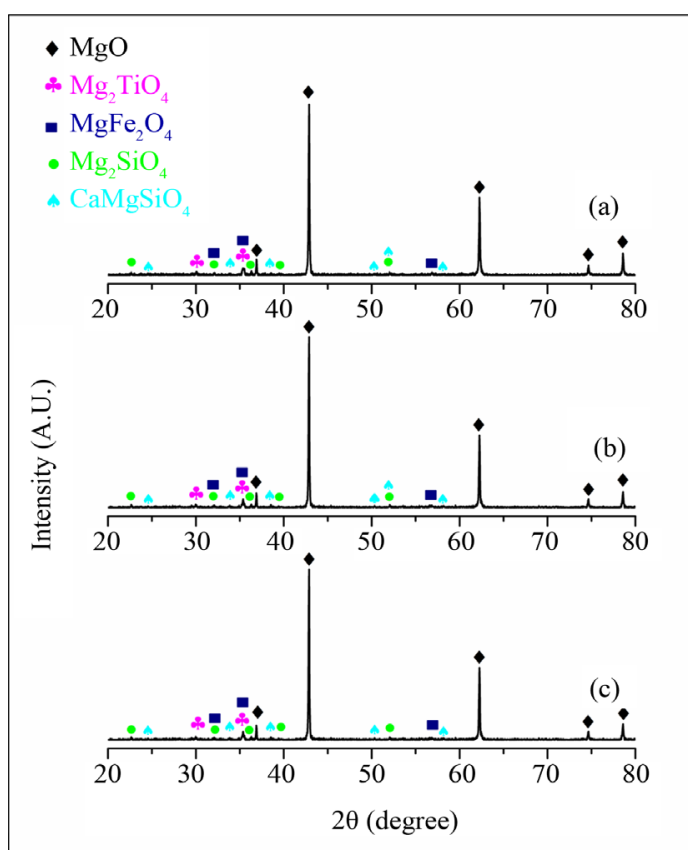

Figure 3. Phase analysis of Indian magnesite with $\mathrm{Fe}_{2} \mathrm{O}_{3}$ additive after sintering at (a) $1550^{\circ} \mathrm{C}$, (b) $1600^{\circ} \mathrm{C}$ and (c) $1650^{\circ} \mathrm{C}$.

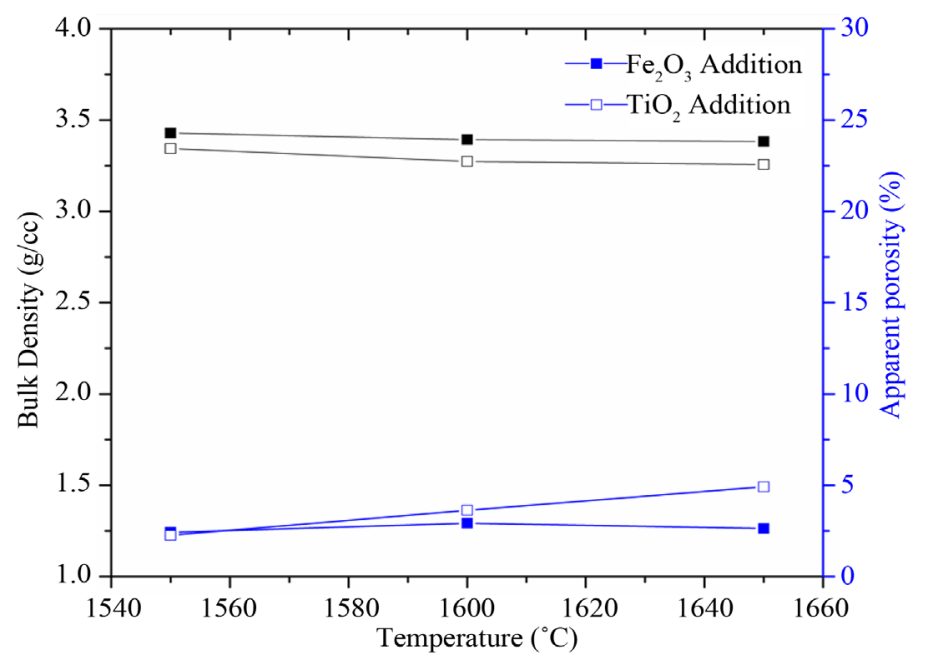

Figure 4. Variation of bulk density and apparent porosity with sintering temperature and different additives. 
increase in specific gravity (Figure 5) with an increase in sintering temperature is observed whereas bulk density almost remains the same. Bulk density and apparent porosity with the addition of $\mathrm{Fe}_{2} \mathrm{O}_{3}$ additive are also shown in Figure 4. Change in specific gravity is shown in Figure 5. It shows that the maximum bulk density of 3.429 $\mathrm{g} / \mathrm{Cc}$ is achieved at the sintering temperature of $1550^{\circ} \mathrm{C}$. With progressing increase in sintering temperature, bulk density almost remains the same for $1600^{\circ} \mathrm{C}$ but after sintering to $1650^{\circ} \mathrm{C}$, specific gravity reduces quite a bit.

\subsection{Microstructural Analysis}

\subsubsection{With $\mathrm{TiO}_{2}$ Addition}

Figure 6 shows the microstructure of the polished section of sintered Magnesite with Titania addition at the temperature of $1600^{\circ} \mathrm{C}$. This microstructure consists of rounded grains with lighter contrast material in the intergranular region. $\mathrm{MgO}$ and $\mathrm{TiO}_{2}$ react during the sintering and to form $\mathrm{Mg}_{2} \mathrm{TiO}_{4}$. In addition to that impurity phase Calcia, reacts with Titania to form stable $\mathrm{CaTiO}_{3}$. Figure 7 shows the EDS elemental map after the sintering at $1650^{\circ} \mathrm{C}$. It shows that the segregated phase at the grain boundary is $\mathrm{CaTiO}_{3}$. The $\mathrm{XRD}$ results also confirm the presence of $\mathrm{CaTiO}_{3}$ phase. Figure 7 elemental analysis shows that inside the grain boundary the main phase is MgO. The presence of Magnesium Silicate phase in the grain boundary can also be seen from the Figure 7.

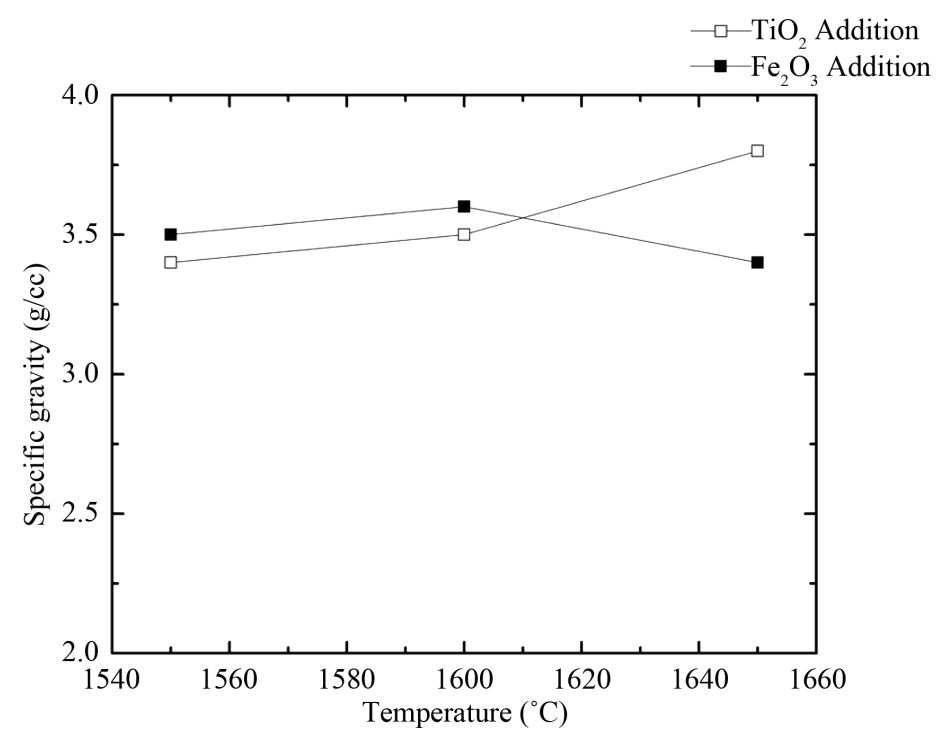

Figure 5. Variation of specific gravity with sintering temperature and different additives.

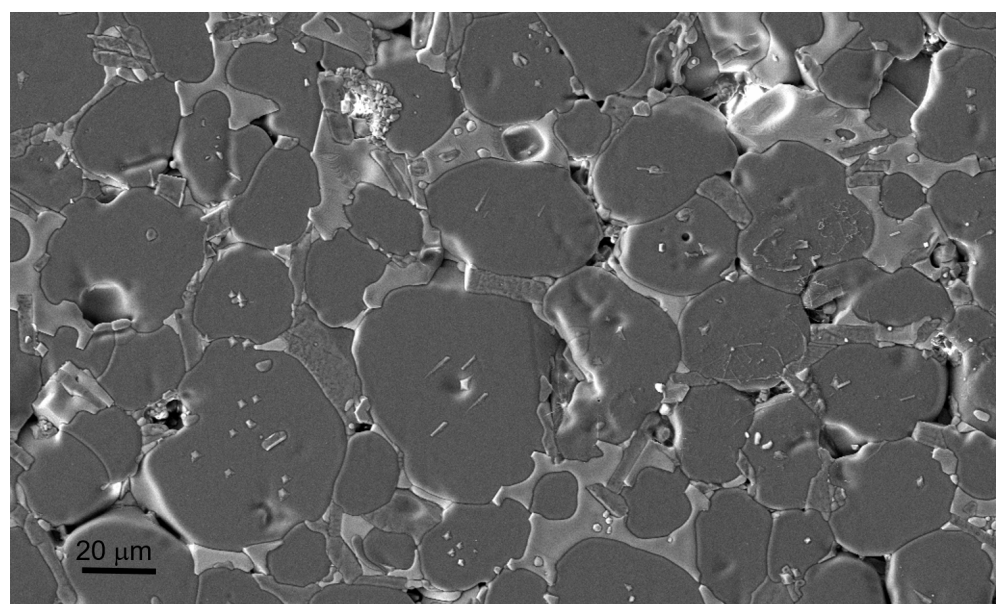

Figure 6. SEM micrograph of Indian magnesite with 2 wt.\% Titania addition after sintering at $1600^{\circ} \mathrm{C}$. 


\subsubsection{With $\mathrm{Fe}_{2} \mathrm{O}_{3}$ Addition}

Figure 8 shows the SEM micrograph of Magnesia with Iron Oxide additive addition. It shows precipitation of a second phase all over the matrix. EDS elemental line scan of the Magnesite with 2 wt.\% Iron Oxide addition is shown in Figure 9. From the line scan, it can be seen that the second phase contains Iron and is well distributed inside the grain boundary. XRD results show the only Iron containing phase in this material is Magnesium Ferrite spinel. Therefore, the second phase, which has precipitated inside the Magnesia grain, likely is the Magnesium Ferrite spinel. This Magnesium Ferrite spinel also shows "Y" shaped morphology and is also oriented in a particular direction inside a grain. The orientation of Magnesium Ferrite spinel, however, changes from one grain to other. Elemental line scan also shows that the $\mathrm{Ca}$ and Si have segregated at the grain boundary region. This phase likely is the $\mathrm{CaMgSiO}_{4}$ as this is the only Ca and Si-containing phase detected by the XRD study.

\section{Discussion}

\subsection{With $\mathrm{TiO}_{2}$ Addition}

In Magnesite with titania addition, asmall increase in specific gravity with an increase in sintering temperature is observed whereas bulk density remains similar. The addition of the $\mathrm{Ti}^{+4}$ results in a cation vacancy in MgO lattices as shown in Figure 10(b). Possibly, the vacancy in the lattice is enhancing the cation movement and mass transfer in the presence of $\mathrm{TiO}_{2}$ and improving the densification. Titanium ion in Magnesium site of MgO lattice
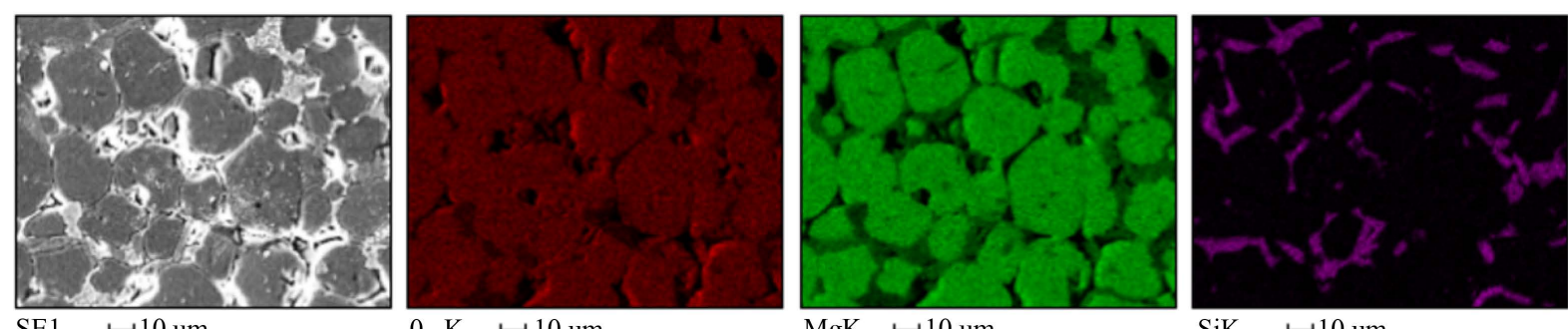

SE1 •10 um $0 \mathrm{~K} \mapsto 10 \mathrm{um}$

MgK $\mapsto 10 \mathrm{um}$

SiK $\mapsto 10$ um
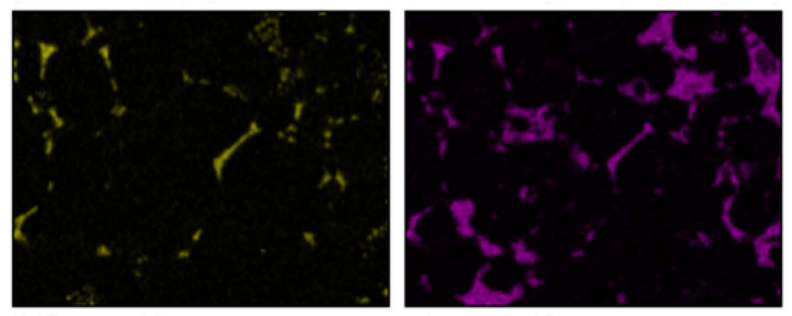

CaK $\mapsto 10$ um

TiK $\mapsto 10$ um

Figure 7. EDS elemental map of Indian magnesite with $2 \mathrm{wt}$.\% Titania addition after sintering at $1650^{\circ} \mathrm{C}$.

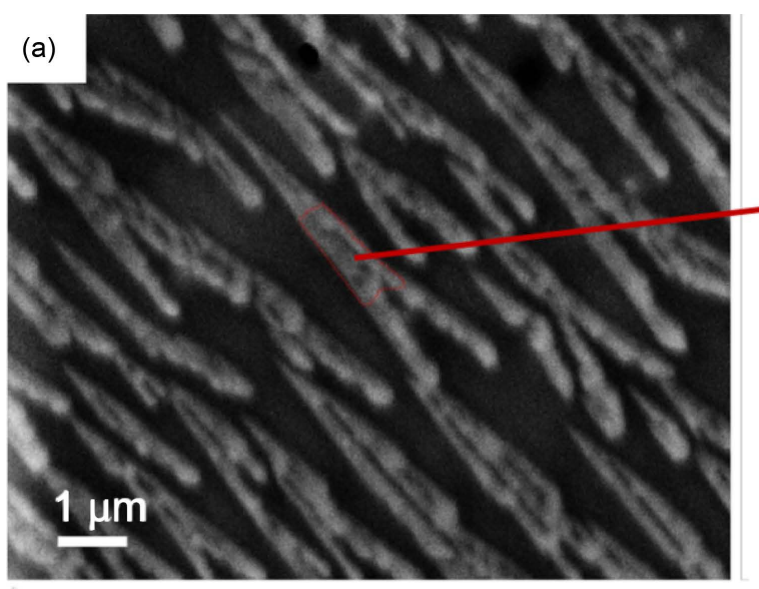

(b)

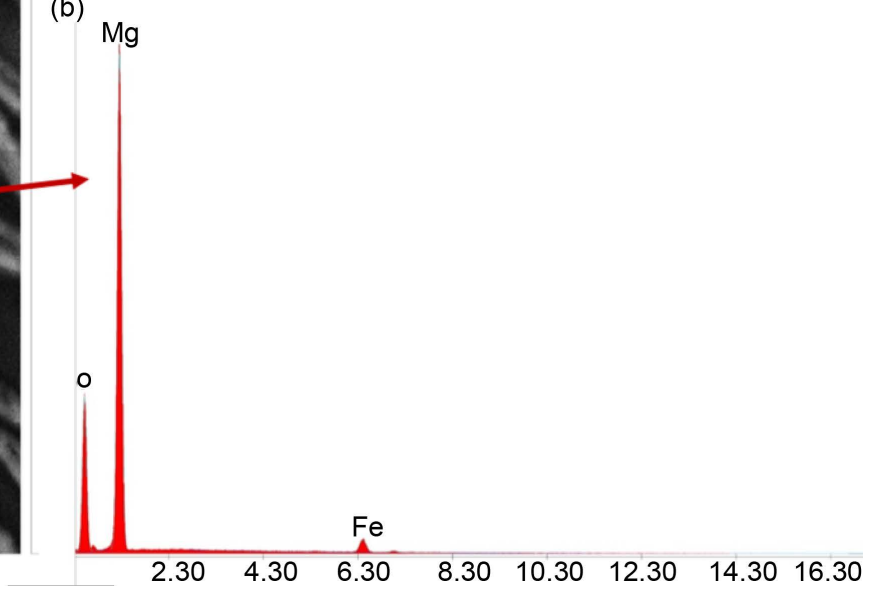

Figure 8. SEM micrograph of Indian magnesite with 2 wt.\% iron oxide addition after sintering at $1600^{\circ} \mathrm{C}$. 

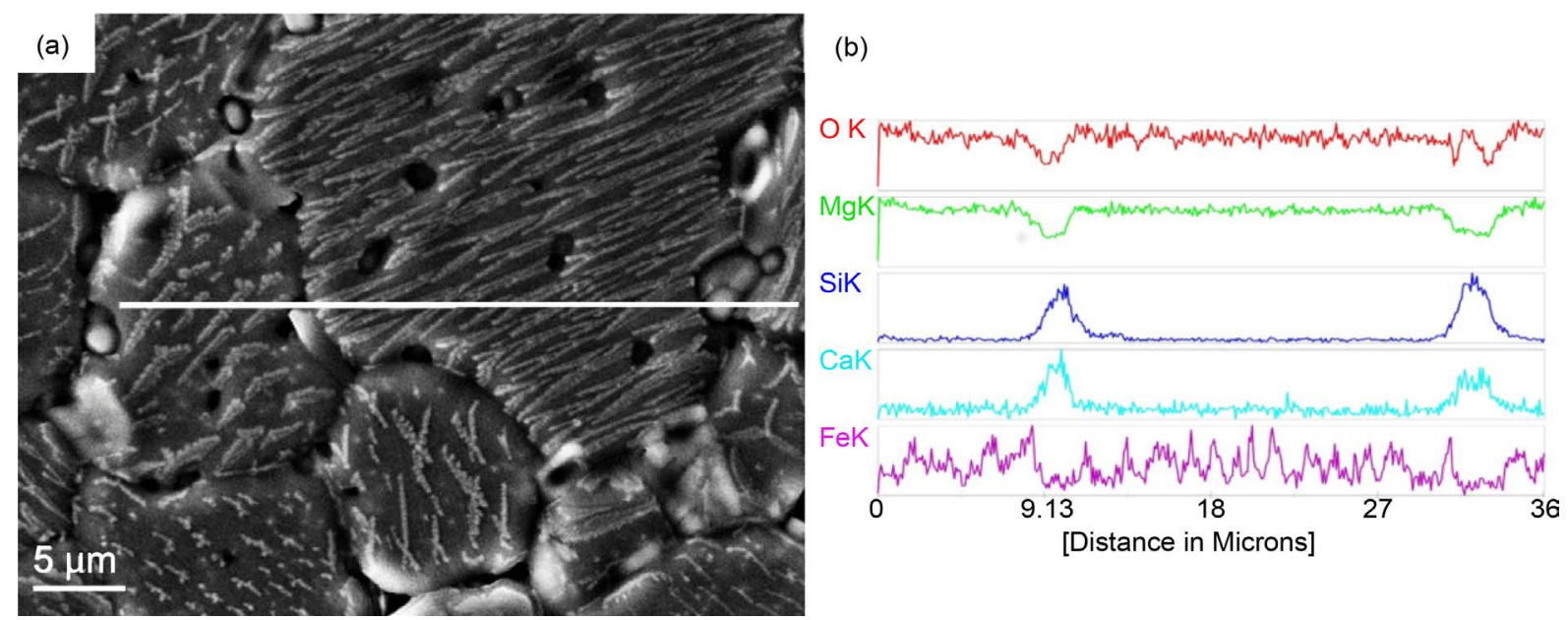

Figure 9. SEM micrograph and elemental line scan of Indian magnesite with 2 wt.\% iron oxide addition after sintering at $1650^{\circ} \mathrm{C}$.

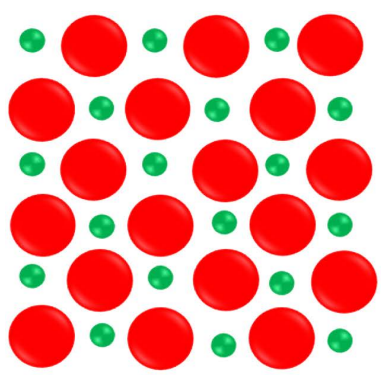

(a)

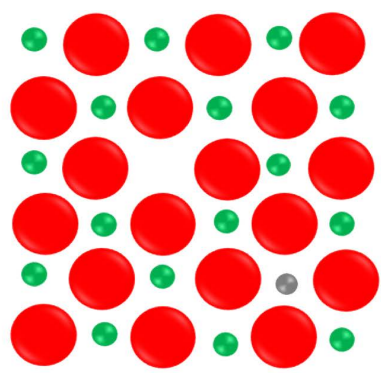

(b)

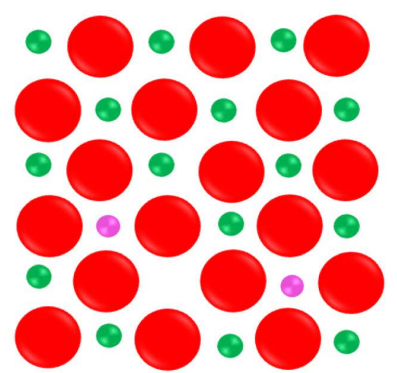

(c)

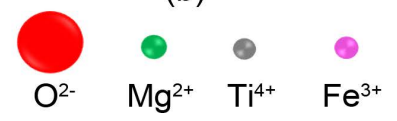

Figure 10. (a) Shows the schematic of MgO system, (b) and (c) show the lattice structure after $\mathrm{Ti}^{+4}$ and $\mathrm{Fe}^{+3}$ addition.

also causes lattice strain due to the larger size of the titanium ion (size of Titanium is $0.068 \mathrm{~nm}$ and that of Magnesium is $0.066 \mathrm{~nm}$ [15]), which also enhances the mass transport process for densification. In the case of $\mathrm{TiO}_{2}$ addition, $\mathrm{Ti}^{4+}$ can substitute $\mathrm{Mg}^{2+}$ ions and form cation vacancies resulting in solid solution at the grain boundaries. Titanium is generally strongly attached to the oxygen interface and concentrates at the grain boundary due to its high chemical reactivity with oxygen [11]. As our SEM micrograph has shown, $\mathrm{Ti}^{4+}$ ion also reacts with Calcia impurity present in the raw material to form calcium titanate as secondary phase across the periclase grain boundaries.

$$
\mathrm{TiO}_{2} \stackrel{2 \mathrm{MgO}}{\longrightarrow} \mathrm{Ti}_{\mathrm{Mg}}^{\circ}+2 \mathrm{O}_{0}^{\mathrm{X}}+\mathrm{V}_{\mathrm{Mg}}^{\prime \prime}
$$

\subsection{With $\mathrm{Fe}_{2} \mathrm{O}_{3}$ Addition}

Additions of $\mathrm{Fe}_{2} \mathrm{O}_{3}$ to $\mathrm{MgO}$ facilitate sintering with increasing sintering temperature except at $1650^{\circ} \mathrm{C}$ at which temperature the densification decreases slightly. The addition of the $\mathrm{Fe}^{+3}$ results in a cation vacancy in $\mathrm{MgO}$ lattices as shown in Figure 10(c). But the vacancy in the lattice is not enhancing the mass transfer and densification in the presence of $\mathrm{Fe}_{2} \mathrm{O}_{3}$, especially at higher temperatures. $\mathrm{Fe}_{2} \mathrm{O}_{3}$ reacts with $\mathrm{MgO}$ to produce Magnesium Ferrite spinel which is known to hinder densification [6]. Possibly this is responsible for lesser densification at a higher temperature. XRD results show Calcia and Silica, which are impurities, reacts with Magnesia to form Calcium Magnesio Silicate which is different from Titania addition, where Calcia reacts with Titania to form Calcium Titanate at the grain boundary.

$$
\mathrm{Fe}_{2} \mathrm{O}_{3} \stackrel{3 \mathrm{MgO}}{\longrightarrow} 2 \mathrm{Fe}_{\mathrm{Mg}}^{\circ}+3 \mathrm{O}_{0}^{\mathrm{X}}+\mathrm{V}_{\mathrm{Mg}}^{\prime \prime}
$$


Table 2. Summary table of specific gravity with the variation of sintering temperature and different additives.

\begin{tabular}{|c|c|c|c|}
\hline \multirow{2}{*}{ Sintering temperature $\left({ }^{\circ} \mathrm{C}\right)$} & \multicolumn{3}{|c|}{ Specific gravity (g/cc) } \\
\hline & Without addition of any additive [10] & Addition of $\mathrm{Fe}_{2} \mathrm{O}_{3}$ additive & Addition of $\mathrm{TiO}_{2}$ additive \\
\hline 1550 & 3.52 & 3.48 & 3.36 \\
\hline 1600 & 3.42 & 3.59 & 3.48 \\
\hline 1650 & 3.55 & 3.41 & 3.75 \\
\hline
\end{tabular}

\subsection{Comparison with as Received Salem Magnesite}

Table 2 shows the comparison of specific gravity between as received Salem Magnesite and Salem Magnesite with Titania and Iron Oxide addition. Both Titania and Iron Oxide addition create cation vacancy and improve densification of Salem Magnesite up to $1600^{\circ} \mathrm{C}$. At $1650^{\circ} \mathrm{C}$, Iron Oxide seems detrimental to the densification, as the specific gravity reduces. This reduction is possibly due to the formation of spinel structure which has been reported to hinder densification [6]. But in the case of Titania addition densification improves with temperature and finally achieves much higher specific gravity compared to the as received Salem Magnesite. This shows that addition of Titania improves sintering and densification of Salem Magnesite.

The main challenge for Salem Magnesite, to be used as a refractory material, is the impurities present namely Silica and Calcia which typically reacts to produce low melting phase (melting point $\sim 1400^{\circ} \mathrm{C}$ ) and degrades the refractoriness. But the addition of Titania prevents this detrimental reaction and produces Calcium Titanate instead which has a much higher melting point $\left(>1800^{\circ} \mathrm{C}\right)$. This will certainly improve the refractoriness of Salem Magnesite.

\section{Conclusion}

The present investigation shows that the Salem Magnesite with Titania and Iron Oxide can be densified to the specific gravity of 3.75 and $3.41 \mathrm{~g} / \mathrm{cc}$ after sintering at $1650^{\circ} \mathrm{C}$ and $2 \mathrm{~h}$. Titania addition improves densification compared to both as received Magnesite and Iron Oxide addition. The presence of Calcium Titanate phase at the grain boundary is also observed in the case of Titania addition. In addition to Calcium Titanate phase, the presence of Magnesium Silicate phase was also observed in the grain boundary. For Iron Oxide addition, MgO grains are directly bonded. Here, precipitation of Magnesium Ferrite spinel is observed inside the grains. These spinel precipitates show "Y" shaped morphology.

\section{Acknowledgements}

The authors would like to thank Jadavpur University, Kolkata and Indian Institute of Science, Bangalore for the experimental facilities. Helpful discussions with Dr. M K Haldar are gratefully acknowledged.

\section{References}

[1] Rigby, G.R., Richardson, H.M. and Ball, F. (1947) The Mineralogical Composition of Calcia Bricks. Transactions and Journal of the British Ceramic Society, 46, 313-329.

[2] Frith, M., Buffrey, T. and Strawbridge, I. (1998) Magnesia: A Refractories Manufacturer Perspective. British Ceramic Transactions, 97, 29-34.

[3] Routschka, G. (2008) Refractory Materials: Pocket Manual; Design, Properties, Testing. Vulkan-Verlag GmbH, Essen.

[4] Son, D., Kim, Y. and Yang, J. (1997) Application of Magnesia-Spinel Castable to the Snorkel in the Rh Degasser. InUNITECR'97. Proceedings of Unified International Technical Conference on Refractories, 5th Biennial Worldwide Congress, Refractories-A Worldwide Technology, 1, 241-246.

[5] Ganesh, I., Bhattacharjee, S., Saha, B.P., Johnson, R. and Mahajan, Y.R. (2001) A New Sintering Aid for Magnesium Aluminate Spinel. Ceramics International, 27, 773-779. http://dx.doi.org/10.1016/S0272-8842(01)00029-3

[6] Layden, G.K. and McQuarrie, M.C. (1959) Effect of Minor Additions on Sintering of MgO. Journal of the American Ceramic Society, 42, 89-92. http://dx.doi.org/10.1111/j.1151-2916.1959.tb14072.x

[7] Lee, Y.B., Park, H.C., Oh, K.D. and Riley, F.L. (1998) Sintering and Microstructure Development in the System MgO-TiO ${ }_{2}$. Journal of Materials Science, 33, 4321-4325. http://dx.doi.org/10.1023/A:1004443728590 
[8] Matsumoto, T. and Kato, A. (1990) Effects of Additives on Sintering of CVD-MgO Powders. Ceramics International, 16, 325-331. http://dx.doi.org/10.1016/0272-8842(90)90084-S

[9] Sarkar, R., Das, S.K. and Banerjee, G. (2003) Effect of Additives on the Densification of Reaction Sintered and Presynthesised Spinels. Ceramics International, 29, 55-59. http://dx.doi.org/10.1016/S0272-8842(02)00089-5

[10] Manna, S. (2012) Studies on the Effect of Additives on Magnesia Refractory Aggregates. Unpublished Bachelor Thesis, Department of Metallurgical and Material Engineering, Jadavpur University, Kolkata.

[11] Nelson, J.W. and Cutler, I.B. (1958) Effect of Oxide Additions on Sintering of Magnesia. Journal of the American Ceramic Society, 41, 406-409. http://dx.doi.org/10.1111/j.1151-2916.1958.tb13512.x

[12] Fresh, D.L. (1956) Methods of Preparation and Crystal Chemistry of Ferrites. Proceedings of the IRE, 44, $1303-1311$. http://dx.doi.org/10.1109/JRPROC.1956.274953

[13] Bron, V.A. (1972) Sintering Processes as a Basis for Obtaining Dense Refractory Powders and Products. Refractories and Industrial Ceramics, 13, 806-813. http://dx.doi.org/10.1007/bf01284141

[14] Cosic, M., Pavlovski, P. and Tkalcec, E. (1989) Activated Sintering of Magnesium Oxide Derived from Serpentine. 1989 Science of Sintering, 21, 161-174.

[15] Carter, C.B. and Norton, M.G. (2007) Ceramic Materials: Science and Engineering 2007. Springer Science \& Business Media, Berlin.

\section{Submit or recommend next manuscript to SCIRP and we will provide best service for you:}

Accepting pre-submission inquiries through Email, Facebook, LinkedIn, Twitter, etc.

A wide selection of journals (inclusive of 9 subjects, more than 200 journals)

Providing 24-hour high-quality service

User-friendly online submission system

Fair and swift peer-review system

Efficient typesetting and proofreading procedure

Display of the result of downloads and visits, as well as the number of cited articles

Maximum dissemination of your research work

Submit your manuscript at: http://papersubmission.scirp.org/ 